\title{
Use of selected social media among youth of Assam
}

\section{Pritismita Gogoi}

Author for correspondence:

Pritismita Gogoi Department of Home Science, Hemo Prova Borbora Girls College, Golaghat (Assam) India Email : pritismitagogoi@gmail. com

Received: 30.08.2019; Revised: 09.10.2019; Accepted: 23.10 .2019

ABSTRACT : The growing dimension of the use of social media among the youth of today cannot be overlooked. The main objectives were as to explore the reasons of using selected social media by the respondents, to find out the extent of using selected social media by the respondents. The study was conducted in Jorhat and Sivasagar districts of Assam. From the study it was found that majority of the youth used WhatsApp $(94.17 \%)$ followed by Facebook (74.17\%), YouTube $(59.17 \%)$, Instagram $(25.00 \%)$, Twitter $(4.17 \%)$ and only 0.83 per cent respondents used LinkedIn. Findings revealed that the youth used social media for communication with friends was ranked I followed by entertainment, chatting, academic work, sharing information, building knowledge, skill learning. It was found that education related area was discussed with teachers by 89.17 per cent youth, general discussion was held with relatives by 67.50 per cent, entertainment with friends by 73.33 per cent and national issues generally discussed with different organization officials by 40.99 per cent youth. It also found that they used social media on daily basis and spent more than two hours on social media.

KEY WORDS: Social media, Youth

- HOW TO CITE THIS PAPER : Gogoi, Pritismita (2019). Use of selected social media among youth of Assam. Asian J. Home Sci., 14 (2) : 304-308, DOI: 10.15740/HAS/AJHS/14.2/304-308. Copyright@ 2019: Hind Agri-Horticultural Society. 